children from 0 to 2 years in an urban west African community. Am $7 \mathrm{Clin}$ Nutr 1988:47:134-8

Thorthat human lung growth. Thorax 1982;37:564-71.

18 Bock GR, Marsh J, eds. The childhood environment and adult disease. Chichester: Wiley, 1991. (Ciba Foundation Symposium No 156.

19 Winick $M$, Noble A. Cellular response in rats during malnutrition at various ages. F Nutrition 1966;89:300-6.

Johnston IDA, Lambert HP, Anderson HR, Patel S. Respiratory morbidity and lung function after whooping cough. Lancet 1983;ii:1104-8.

21 Britten N, Wadsworth J. Long term respiratory sequelae of whooping cough in nationally representative sample. $B M 7$ 1986;292:441-4.

22 Swansea Research Unit of the Royal College of General Practitioners. Respiratory sequelae of whooping cough. BMF 1985;290:1937-40.
23 Halliday JL. An inquiry into the relationship between housing conditions and the incidence and fatality of measles. London: Medical Research Council, 1928. MRC Specia Report Series No 120 .

24 Gunawardena KA, Houston K, Smith AP. Evaluation of the turbine pocket spirometer. Thorax 1987;42:689-93.

25 Hosie HE, Nimmo WS. Measurement of $\mathrm{FEV}_{1}$ and FVC. Comparison of pocket spirometer with the Vitalograph. Anaesthesia 1988;43:233-8.

26 Chen Y, Pederson LL, Lefcoe NM. Passive smoking and low birth weight Lancet 1989;ii:54-5.

27 Davis DL. Paternal smoking and fetal health. Lancet 1991;337:123.

(Accepted 4 fuly 1991)
Aker University Hospital, 0514 Oslo 5, Norway

Helge Kapelrud, MD, senior registrar

Hans-Jacob Bangstad, MD, senior registrar

Knut Dahl-Jørgensen, MD, consultant

Kristian F Hanssen, MD, consultant

Institute of Medica Genetics, University of Oslo, Box 1036 Blindern, 0315 Oslo 3, Norway

Kåre Berg, $\mathrm{MD}$, professor

Correspondence to: $\mathrm{Dr} \mathrm{H}$ Kapelrud, Department of Medicine, Hamar Sjukehus, 2300 Hamar, Norway.

BMF 1991;303:675-8

\title{
Serum $L p(a)$ lipoprotein concentrations in insulin dependent diabetic patients with microalbuminuria.
}

\author{
Helge Kapelrud, Hans-Jacob Bangstad, Knut Dahl-Jørgensen, Kåre Berg, Kristian F Hanssen
}

Abstract

Objective-To compare the serum concentrations of lipoproteins and apolipoproteins in insulin dependent diabetic patients with and without microalbuminuria.

Design-Cross sectional study.

Setting-Paediatric and medical outpatient clinic at a university hospital.

Patients - 76 insulin dependent diabetic patients: 41 with microalbuminuria (20 males, 21 females) and 35 controls without microalbuminuria (18 males, 17 females). The two groups were similar with respect to age, duration of disease, and haemoglobin $A_{1 c}$ concentrations before the study.

Main outcome measures-Serum concentrations of $L p(a)$ lipoprotein, total cholesterol, high density lipoprotein cholesterol, very low density lipoprotein cholesterol, low density lipoprotein cholesterol, triglycerides, and apolipoproteins A-I, A-II, and B.

Results-Median serum $L p(a)$ lipoprotein concentration was $10.0 \mathrm{mg} / 100 \mathrm{ml}$ in the microalbuminuric group and $4.9 \mathrm{mg} / 100 \mathrm{ml}$ in the control group $(p=0.007) .17(41 \%)$ of the microalbuminuric patients and five $(14 \%)$ of the control patients had $\mathbf{L}$ (a) lipoprotein values above the upper quartile of a normal population. Median serum triglycerides concentrations in the microalbuminuric and control groups were $1.15 \mathrm{mmol} / \mathrm{l}$ and $0.88 \mathrm{mmol} / \mathrm{l}$ respectively $(\mathbf{p}=\mathbf{0} \cdot 03)$. Median very low density lipoprotein cholesterol concentration was $0.52 \mathrm{mmol} / \mathrm{l}$ in the microalbuminuric group and $0.40 \mathrm{mmol} / 1$ in the control group $(p=0.03)$. No significant differences in serum concentrations of total cholesterol, high density lipoprotein cholesterol, low density lipoprotein cholesterol, or apolipoproteins A-I, A-II, and $B$ were found between the groups.

Conclusions-Serum concentrations of $L p(a)$ lipoprotein are twice as high in insulin dependent diabetic patients with microalbuminuria as in those without microalbuminuria. Increased concentrations of $L p(a)$ lipoprotein might partly explain the increased morbidity and mortality from cardiovascular disease observed among patients with diabetic nephropathy.

\section{Introduction}

Mortality is 40 times higher in insulin dependent diabetic patients with nephropathy than in those without this complication. ${ }^{1}$ Much of the excess mortality is caused by cardiovascular disease. ${ }^{2}$ Forty per cent of diabetic patients develop coronary heart disease within six years after manifesting nephropathy. ${ }^{3}$ Such patients have increased blood pressure, atherogenic lipid and lipoprotein patterns, and changes in the balance between coagulation and fibrinolysis in favour of coagulation, ${ }^{+6}$ but these cardiovascular risk factors cannot explain the substantial increase in mortality. Patients with incipient nephropathy (persistent microalbuminuria) may have the same cardiovascular risk factors, but to a lesser extent. ${ }^{48}$ Diabetic patients with incipient nephropathy are at risk of developing proteinuria within 10 years. ${ }^{9} 10$

$\mathrm{Lp}$ (a) lipoprotein contains less lipid and more protein than low density lipoprotein, although both contain apolipoprotein B. Lp(a) lipoprotein has a unique long, highly glycated polypeptide chain ( $\mathrm{Lp}(\mathrm{a})$ apolipoprotein) which carries the $L p(a)$ antigens. The gene for $\mathrm{Lp}(\mathrm{a})$ apolipoprotein has been cloned and extensive homology with plasminogen has been found."

The concentration of $\mathrm{Lp}(\mathrm{a})$ lipoprotein in serum is determined genetically. ${ }^{12-16}$ Since the first report in $1974,{ }^{17}$ several investigators have confirmed that a high $\mathrm{Lp}$ (a) lipoprotein concentration is an independent risk factor for cardiovascular disease. ${ }^{16-20} \mathrm{Lp}(\mathrm{a})$ lipoprotein has been detected in atherosclerotic lesions in amounts reportedly reflecting the serum concentration, ${ }^{21}$ suggesting that it may be atherogenic. Because of the homology with plasminogen it has been hypothesised that the $\operatorname{Lp}(\mathrm{a})$ lipoprotein may provide a link between atherogenesis and thrombus formation..$^{22}$

As diabetic nephropathy is linked with atherosclerotic disease and as the diabetic patients with microalbuminuria are those who develop nephropathy, we investigated whether insulin dependent diabetic patients with microalbuminuria have an increased plasma concentration of $L p(a)$ lipoprotein compared with diabetic controls without microalbuminuria.

\section{Patients and methods}

We recruited 41 patients, 20 males and 21 females with insulin dependent diabetes mellitus and microalbuminuria from our hospital's outpatient clinic on the basis of hospital records of microalbuminuria. All patients had had onset of diabetes before the age of 30 . We defined microalbuminuria as albumin excretion $\geqslant 15 \mu \mathrm{g} / \mathrm{min}$ and $\leqslant 200 \mu \mathrm{g} / \mathrm{min}$ in at least two consecutive or two of three timed overnight urine samples. The urine samples did not show leucocyturia when tested by dipsticks. None of the patients had a history of non-diabetic renal disease, and none had ketoacidosis at the time of sampling.

The patients with microalbuminuria were compared with 35 insulin dependent diabetic patients without microalbuminuria. The sex ratio, age, duration of diabetes, and concentrations of haemoglobin $A_{l c}$ (means of three values) were similar in both groups. Haemoglobin $A_{1 c}$ concentrations were measured over 12 to 15 months, starting from 12 to 28 months and 
ending from 0 to 23 months before the blood sampling for determination of lipid and apolipoprotein concentrations. The mean haemoglobin $\mathrm{A}_{\mathrm{lc}}$ concentration was calculated by using the measurements taken during the inclusion period and that taken at the time of blood sampling for measuring lipoprotein concentrations. One person in the microalbuminuric group was being treated for hypertension with enalapril and frusemide, and one person in the control group was taking prazosin for hypertension. Four women in the microalbuminuric group and six women in the control group used combined oestrogen and gestagen contraceptive pills, and two women in the control group used gestagen contraceptive pills. One person in the microalbuminuric group took carbamazepine for epilepsy. Table I summarises the clinical details of the two groups.

The blood samples were drawn between $8 \mathrm{am}$ and $10 \mathrm{am}$ after an overnight fast and before insulin was taken. The samples were centrifuged within an hour and the plasma stored at $-70^{\circ} \mathrm{C}$.

Total serum cholesterol, high density lipoprotein cholesterol, and triglyceride concentrations were measured by enzymatic methods. ${ }^{2324}$ Very low density lipoprotein cholesterol concentration was calculated by Friedewald's formula (very low density lipoprotein cholesterol $=$ triglycerides $\times 0.45),{ }^{25}$ and low density lipoprotein cholesterol concentration was calculated by subtracting the sum of high density lipoprotein cholesterol and very low density lipoprotein cholesterol concentrations from the total cholesterol concentration. Apolipoprotein A-I and apolipoprotein B were measured by turbidimetry with antiserum and standard reagents from Behringwerke AG, Marburg. Apolipoprotein A-II was measured by radial immunodiffusion with antiserum from Boehringer Mannheim, Germany.

The albumin concentration in urine was measured by a immunoturbidometric method. The variation coefficient in the range of $10-50 \mathrm{mg} / \mathrm{l}$ was $4 \cdot 7 \%$. Lp(a) lipoprotein was measured by quantitative immunoelectrophoresis with highly specific antiserum prepared at the Institute of Medical Genetics, University of Oslo, incorporated in the agarose gel. Reference human serum with a high concentration of $L p(a)$ lipoprotein was included at four dilutions in each electrophoresis run. The concentration of $L p(a)$ lipoprotein in the reference serum was determined by comparing precipitin "rockets" obtained with purified $\mathrm{Lp}$ (a) lipoprotein preparations whose protein concentrations had been determined by the micro-Kjeldahl method. Reproducibility was investigated by testing split serum samples blinded; this gave a correlation coefficient of $0 \cdot 98 .{ }^{19}$ Concentration of $L p(a)$ lipoprotein is given as $\mathrm{mg}$ protein $/ 100 \mathrm{ml}$ as to calculate a molarity the protein result would have to be multiplied by a correction factor taking into account the relative

TABLE I-Clinical details of insulin dependent diabetic patients with and without microalbuminuria

\begin{tabular}{|c|c|c|c|}
\hline & $\begin{array}{l}\text { With microalbuminuria } \\
\qquad(\mathrm{n}=41)\end{array}$ & $\begin{array}{l}\text { Without microalbuminuria } \\
\qquad(\mathrm{n}=35)\end{array}$ & $\mathrm{p}$ Value \\
\hline Male/female & $20 / 21$ & $18 / 17$ & \\
\hline Median (range) age (years) & $19(14-49)$ & $20(15-43)$ & $0 \cdot 16$ \\
\hline $\begin{array}{l}\text { Median (range) duration of } \\
\text { diabetes (years) }\end{array}$ & $13(7-33)$ & $14(7-33)$ & $0 \cdot 44$ \\
\hline $\begin{array}{l}\text { Median (range) body mass index } \\
\left(\mathrm{kg} / \mathrm{m}^{2}\right)\end{array}$ & $23 \cdot 8(19 \cdot 5-31 \cdot 4)$ & $23 \cdot 8(20 \cdot 1-30 \cdot 0)$ & $0 \cdot 29$ \\
\hline $\begin{array}{l}\text { Median (range) haemoglobin } \\
\mathrm{A}_{\mathrm{lc}}(\%)\end{array}$ & $8 \cdot 8(6 \cdot 3-14 \cdot 5)$ & $9 \cdot 4(7 \cdot 0-11 \cdot 2)$ & 0.32 \\
\hline $\begin{array}{l}\text { Median (range) mean haemoglobin } \\
\mathrm{A}_{\mathrm{lc}}(\%)\end{array}$ & $9 \cdot 4(6 \cdot 7 \cdot 12 \cdot 6)$ & $9 \cdot 0(6 \cdot 3-11 \cdot 9)$ & 0.08 \\
\hline $\begin{array}{l}\text { Median (range) dose of insulin } \\
(\mathrm{IU} / \mathrm{kg} / \text { day })\end{array}$ & $0.90(0.49-1.28)$ & $0 \cdot 83(0 \cdot 40-1 \cdot 28)$ & 0.09 \\
\hline $\begin{array}{l}\text { Median (range) mean albumin } \\
\text { excretion rate }(\mu \mathrm{g} / \mathrm{min})^{\star}\end{array}$ & $30(14-186)$ & $5(2-13)$ & $<0.001$ \\
\hline
\end{tabular}

${ }^{\star}$ In two patients some of the albumin excretion rates were given as $\mathrm{mg} / 24 \mathrm{~h}$. As the albumin excretion rate is about $25 \%$ higher when measured over $24 \mathrm{~h}$ rather than overnight the results were converted to $\mu \mathrm{g} / \mathrm{min}$ and reduced by $25 \%$ to obtain comparable values.

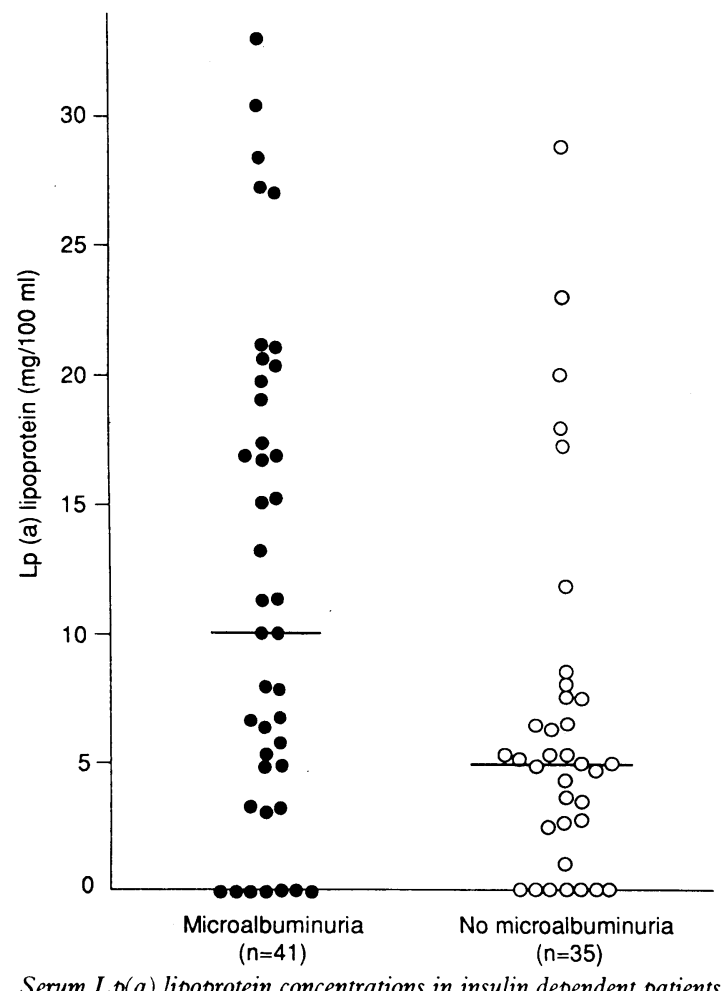

Serum $L p(a)$ lipoprotein concentrations in insulin dependent patients with and without microalbuminuria. Median value in each group depicted by horizontal line

amount of protein in $\mathrm{Lp}(\mathrm{a})$ lipoprotein, which varies among isoforms of the polypeptide chain carrying the $\mathrm{Lp}(\mathrm{a})$ antigen. All apolipoprotein concentrations are also given as $\mathrm{mg} / 100 \mathrm{ml}$.

The Mann-Whitney $U$ test was used to compare distributions. A value below 0.05 was taken as signifcant. Correlation between parameters was given as Pearson's $r$ (least square method). The proportions of the groups having a $L p(a)$ lipoprotein value above the upper quartile were compared by using $\chi^{2}$ test with Yates's correction.

\section{Results}

The median $\mathrm{Lp}(\mathrm{a})$ lipoprotein concentration in the microalbuminuric group $(10 \cdot 0 \mathrm{mg} / 100 \mathrm{ml})$ was significantly higher than that in the control group $(4.9 \mathrm{mg} /$ $100 \mathrm{ml} ; \mathrm{p}=0.007$ ) (figure). The association between $\mathrm{Lp}(\mathrm{a})$ lipoprotein and cardiovascular disease is largely confined to patients with values above the upper quartile of the distribution of serum $L p(a)$ concentrations. ${ }^{19}$ In healthy unrelated individuals examined in the same laboratory with the same technique, the upper quartile was $13.55 \mathrm{mg} / 100 \mathrm{ml}$ (data not shown). In our study 17 patients (41\%) in the microalbuminuric group compared with five (14\%) in control group had serum $L p(a)$ lipoprotein values above the upper quartile $(\mathrm{p}=0 \cdot 02)$.

In the control group the haemoglobin $\mathrm{A}_{\mathrm{lc}}$ concentration at the time of blood sampling and the mean concentration both showed a significant positive correlation with the serum $\mathrm{Lp}(\mathrm{a})$ lipoprotein concentration $(r=0.50, \mathrm{p}=0.001$ and $r=0.35, \mathrm{p}=0.02$, respectively). In the microalbuminuric group the correlations were not significant $(r=0.21, \mathrm{p}=0.09$ at the time of blood sampling and $r=0.20, \mathrm{p}=0.11$ for mean concentration).

The median concentrations of serum triglycerides and very low density lipoprotein cholesterol were significantly higher in the microalbuminuric group than in the control group (table II). Median serum concentrations of apolipoprotein A-II were identical in the two groups, and total cholesterol, high density lipoprotein cholesterol, low density lipoprotein 
TABLE II-Median (95\% confidence interval) serum concentrations of lipids and lipoprotein in insulin dependent diabetic patients with and without microalbuminuria

\begin{tabular}{|c|c|c|c|}
\hline & $\begin{array}{l}\text { With microalbuminuria } \\
\qquad(\mathrm{n}=41)\end{array}$ & $\begin{array}{l}\text { Without microalbuminuria } \\
\qquad(\mathrm{n}=35)\end{array}$ & p Value \\
\hline \multicolumn{4}{|l|}{$\mathrm{Lp}(\mathbf{a})$ lipoprotein (mg protein) } \\
\hline $100 \mathrm{ml})$ & $10 \cdot 0(5 \cdot 7$ to $16 \cdot 8)$ & $4.9(3.4$ to 6.4$)$ & $0 \cdot 007$ \\
\hline Cholesterol $(\mathrm{mmol} / \mathrm{l})$ & $5 \cdot 3(4 \cdot 8$ to $5 \cdot 7)$ & $4 \cdot 9(4 \cdot 6$ to $5 \cdot 0)$ & $0 \cdot 11$ \\
\hline Triglycerides $(\mathrm{mmol} / \mathrm{l})$ & $1.15(1.01$ to 1.48$)$ & $0.88(0.76$ to 0.99$)$ & 0.03 \\
\hline $\begin{array}{l}\text { High density lipoprotein } \\
\text { cholesterol }(\mathrm{mmo} / \mathrm{l})\end{array}$ & $1 \cdot 20(1.05$ to 1.32$)$ & $1 \cdot 18(1 \cdot 10$ to $1 \cdot 29)$ & $0 \cdot 43$ \\
\hline $\begin{array}{l}\text { Very low density lipoprotein } \\
\text { cholesterol }(\mathrm{mmol} / \mathrm{l})\end{array}$ & $0.52(0.45$ to 0.67$)$ & $0.40(0.34$ to 0.45$)$ & $0 \cdot 03$ \\
\hline $\begin{array}{l}\text { Low density lipoprotein cholesterol } \\
(\mathrm{mmol} / \mathrm{l})\end{array}$ & $3.54(2.83$ to 4.06$)$ & $3.11(3.02$ to 3.56$)$ & $0 \cdot 18$ \\
\hline $\begin{array}{l}\text { Apolipoprotein A-I (mg protein/ } \\
100 \mathrm{ml} \text { ) } \\
\text { Apolipoprotein A-II (mg protein/ }\end{array}$ & $118(109$ to 124$)$ & $111(105$ to 119$)$ & $0 \cdot 10$ \\
\hline $\begin{array}{l}\text { Apolpoprotein A-H (mg protein/ } \\
100 \mathrm{ml} \text { ) } \\
\text { Apolipoprotein B (mg protein/ }\end{array}$ & $41(38$ to 44$)$ & $41(39$ to 42$)$ & $0 \cdot 28$ \\
\hline $100 \mathrm{ml}$ ) & $109(95$ to 119$)$ & $97(81$ to 106$)$ & $0 \cdot 08$ \\
\hline
\end{tabular}

cholesterol, apolipoprotein A-I, and apolipoprotein B concentrations were not significantly higher in the microalbuminuric group (table II).

\section{Discussion}

We have shown that insulin dependent diabetic patients with microalbuminuria have a significantly higher concentration of $\mathrm{Lp}(\mathrm{a})$ lipoprotein than those without microalbuminuria of the same sex, age, duration of diabetes, and haemoglobin $\mathrm{A}_{1 \mathrm{c}}$ concentration. This difference cannot be explained by differences in blood glucose control as the haemoglobin $A_{1 \mathrm{c}}$ concentration was similar in the two groups.

Significantly more microalbuminuric patients than control patients had $\mathrm{Lp}(\mathrm{a})$ lipoprotein concentrations above the upper quartile of the normal distribution. The number was higher than expected in the microalbuminuric group and lower than expected in the control group. As an increased plasma concentration of $\mathrm{Lp}(\mathrm{a})$ lipoprotein is strongly correlated with the risk for coronary heart disease, finding a higher value in microalbuminuric diabetic patients may be important in understanding the increased prevalence of cardiovascular disease in diabetic patients with nephropathy. It is remarkable that $\mathrm{Lp}(\mathrm{a})$ lipoprotein concentrations were so different in the two groups of young insulin dependent diabetic patients without any clinical signs of arteriosclerotic disease, that differed only in the excretion of small amounts of urinary albumin.

Serum $\mathrm{Lp}(\mathrm{a})$ lipoprotein concentrations vary 1000 fold among individuals, and the distribution is skewed in Caucasian populations, with a peak in the low range and a tail of higher values. ${ }^{152627}$ The serum concentration is independent of age and sex, and it is not influenced by lipid lowering diets. ${ }^{28}$ However, recent investigations have shown a correlation between $\mathrm{Lp}(\mathrm{a})$ lipoprotein concentrations and parameters of glycaemic control in insulin dependent diabetic patients. ${ }^{29}{ }^{30} \mathrm{We}$ found a significant correlation between $\mathrm{Lp}(\mathrm{a})$ lipoprotein and haemoglobin $\mathrm{A}_{\mathrm{Ic}}$ concentration only in the patients without microalbuminuria. $L p(a)$ lipoprotein can accumulate in artery walls, ${ }^{2131}$ and $\mathrm{Lp}(\mathrm{a})$ apolipoprotein competes with plasminogen for the binding sites on the endothelial cell surface. ${ }^{32}$ $\mathrm{Lp}$ (a) lipoprotein has been shown to bind tissue type plasminogen activator in vitro, thus inhibiting activation of plasminogen. ${ }^{33} \mathrm{Lp}(\mathrm{a})$ lipoprotein may therefore contribute to the development of atherothrombotic disease by inhibiting fibrinolysis.

The fibrinolytic system is changed in diabetic patients with microalbuminuria. ${ }^{6}$ Increased concentrations of $\mathrm{Lp}(\mathrm{a})$ lipoprotein might bind more tissuetype plasminogen activator leading to less release of this factor into the blood as described in insulin dependent diabetic patients with microalbuminuria. ${ }^{6}$

The serum concentrations of triglycerides and very low density lipoprotein cholesterol were significantly higher in the microalbuminuric patients. The very low density lipoprotein cholesterol concentrations are in accordance with the findings of others, while the difference in triglyceride concentration between the groups is somewhat greater in our series. ${ }^{45}$

Only about $35 \%$ of patients with insulin dependent diabetes develop nephropathy. ${ }^{34}$ Glycaemic control is a crucial determinator for the development of nephropathy, ${ }^{35-37}$ but there also is a genetic factor. ${ }^{38}$ As the serum concentration of $\mathrm{Lp}(\mathrm{a})$ lipoprotein is genetically determined in healthy populations $\operatorname{Lp}(\mathbf{a})$ lipoprotein may be associated with the genetic predisposition to diabetic nephropathy.

This study was supported by the Norwegian Diabetes Association. Work at the Institute of Medical Genetics, University of Oslo, was supported by the Norwegian Council on Cardiovascular Diseases and the Norwegian Research Council for Science and the Humanities. We thank Miss Elisabeth Møkleby for technical help.

1 Borch-Johnsen K, Andersen PK, Deckert T. The effect of proteinuria on relative mortality in type 1 (insulin-dependent) diabetes mellitus. Diabetologia 1985;28:590-6.

2 Borch-Johnsen K, Kreiner S. Proteinuria: value as predictor of cardiovascular mortality in insulin dependent diabetes mellitus. BMJ 1987;294:1651-4.

3 Jensen T, Borch-Johnsen K, Kofoed-Enevoldsen A, Deckert T. Coronary heart disease in young type $l$ (insulin-dependent) diabetic patients with and without diabetic nephropathy: incidence and risk factors. Diabetologia 1987;30:144-8.

4 Jensen T, Stender S, Deckert T. Abnormalities in plasma concentrations of lipoproteins and fibrinogen in type 1 (insulin-dependent diabetic) patients with increased urinary albumin excretion. Diabetologia 1988;31:142-5.

5 Vannini P, Ciavarella A, Flammini M, Bargossi AM, Forlani G, Borgnino LC, et al. Lipid abnormalities in insulin-dependent diabetic patients with albuminuria. Diabetes Care 1984;7:151-4.

6 Jensen T, Bjerre-Knudsen J, Feldt-Rasmussen B, Deckert T. Features of endothelial dysfunction in early diabetic nephropathy. Lancet 1989;i:461-3.

7 Deckert T, Feldt-Rasmussen B, Borch-Johnsen K, Kofoed-Enevoldsen A Albuminuria reflects widespread vascular damage. The Steno hypothesis. Albuminuria reflects widesp
Diabetologia 1989;32:219-26.

8 Jones SL, Close CF, Mattock MB, Jarrett RJ, Keen H, Viberti GC. Plasma lipid and coagulation factor concentrations in insulin dependent diabetics with microalbuminuria. BMF 1989;298:487-90.

9 Mogensen CE, Christensen CK. Predicting diabetic nephropathy in insulin dependent patients. $N$ Engl f Med 1984;311:89-93.

10 Cooper ME, Frauman A, O'Brien RC, Seeman E, Murray RML, Jerums G. Progression of proteinuria in type 1 and type 2 diabetes. Diabetic Me 1988;5:361-8

11 McLean JW, Tomlinson JE, Kuang WJ, Eaton DL, Chen EY, Fless GM, et al. cDNA sequence of human apolipoprotein (a) is homologous to plasminogen. Nature 1987;330:132-7.

12 Berg K. A new serum type system in man: the Lp system. Acta Pathologica el Microbiologica Scandinavica 1963;59:369-82.

13 Berg K. Genetics of coronary heart disease. In: Steinberg AG, Bearn AG Motulsky AG, Childs B, eds. Progress in medical genetics. Philadelphia: WB Saunders, 1983:35-90.

14 Berg K. Lp(a) lipoprotein: an overview. In: Scanu A, ed. Lipoprotein $(a)$. New York: Academic Press, 1990:1-23.

15 Berg K. Genetics of atherogenic Lp(a) lipoprotein. In: Berg K, Retterstøl N, Refsum S, eds. From phenotype to gene in common disorders. Copenhagen Munksgaard, 1990:138-62.

16 Morton NE, BergK, Dahlén G, Ferrell RE, Rhoads GG. Genetics of the Lp(a) lipoprotein in Japanese-Americans. Genet Epidemiol 1985;2:113-21.

17 Berg K, Dahlén G, Frick MH. Lp(a) lipoprotein and pre- $\beta_{1}-$ lipoprotein in patients with coronary heart disease. Clin Genet 1974;6:230-5.

18 Frick $M H$, Dahlén G, Berg K, Valle M, Hekali P Serum lipids in angiographically assessed coronary atherosclerosis. Chest 1978;73:62-5.

19 Rhoads GG, Dahlén G, Berg K, Morton NE, Dannenberg AL. Lp(a) lipoprotein as a risk factor for myocardial infarction. $\mathcal{F} A M A$ 1986;256: $2540-4$

20 Rosengren A, Wilhelmsen L, Eriksson E, Risberg B, Wedel H. Lipoprotein (a) and coronary heart disease: a prospective case-control study in a genera population sample of middle aged men. BMF 1990;301:1248-51.

21 Rath M, Niendorf A, Reblin T, Dietel M, Krebber HJ, Beisiegel U. Detection and quantitation of lipoprotein (a) in the arterial wall of 107 coronary bypass patients. Arteriosclerosis 1989;9:579-92.

22 Brown MS, Goldstein JL. Teaching old dogmas new tricks. Nature 1987;330 $113-4$

23 Röschlau P, Bernt E, Gruber W. Enzymatic determination of total cholesterol in serum. Z Klin Chem Klin Biochem 1974;12:403-7.

24 Wahlefeld $\mathrm{AW}$. Triglycerides. Determination after enzymatic hydrolysis. In: Bergmeyer $\mathrm{HU}$, ed. Methods of enzymatic analysis. 2nd ed. New York: Academic Press, 1974:1831-5.

25 Friedewald WT, Levy R, Fredrickson DS. Estimations of serum low density lipoprotein cholesterol without use of preparative ultrasentrifuge. Clin lipoprotein cholesterol
Chem 1972;18:499-502.

26 Guvton JR, Dahlen GH, Patsch W, Kautz JA, Gotto AM. Relationship of plasma lipoprotein $\mathrm{Lp}(\mathrm{a})$ levels to race and to apolipoprotein B. Arterioplasma lipoprotein $L p$
sclerosis $1985: 5: 265-72$.

27 Schriewer H, Assmann G, Sandkamp M. The relationship of lipoprotein (a) LP (a)) to risk factors of coronary heart disease. $\mathcal{F}$ Clin Chem Clin Biochem 1984;22:591-6.

28 Masarei JRL, Rouse IL, Lynch WJ, Robertson K, Vandongen R, Beilin LJ. Effect of a lactovegetarian diet on serum concentrations of cholesterol, triglyceride, HDL-C, HDL2-C, HDL3-C, apoprotein B and Lp(a). Am Clin Nutr 1984;40:468-79.

29 Davidoff E, Bruckert A, Grimaldi A, Truffert J, De Gennes JL, Thervet F. 
Lipoprotein (a) level in type I diabetes (abstract). Diabetes 1989;38(suppl 2):70A and its correlation with metabolic control (abstract). Diabetes 1990;39 (suppl 1):64A.

31 Cushing GL, Gaubatz JW, Nava ML, Burdick BJ, Bocan TM, Guyton JR, et al. Quantitation and localization of apolipoprotein (a) and B in coronary artery bypass vein grafts resected at re-operation. Arteriosclerosis 1989;

32 Miles LA, Fless GM, Levin EG, Scanu AM, Plow EF. A potential basis for the thrombotic risks associated with lipoprotein (a). Nature 1989;339:301-3.

33 Simon DI, Fless GM, Scanu Am, Loscalzo J. Tissue-type plasminoge activator binds to and is inhibited by lipoprotein (a) (abstract). Circulation 1990;82 (suppl III):599.

34 Andersen AR, Christiansen JS, Andersen JK, Kreiner S, Deckert T. Diabetic nephropathy in type 1 (insulin-dependent) diabetes: an epidemiological study. Diabetologia 1983;25:496-501.
35 Dahl-Jorgensen K, Hanssen KF, Kierulf P, Biøro T, Sandvik L, Aagenæs $\varnothing$ Reduction of urinary albumin excretion after 4 years of continuous subcttaneous insulin infusion in insulin-dependent diabetes mellitus. The Osto Study. Acta Endocrinol (Copenh) 1988:117:19-25.

36 Feldt-Rasmussen B, Mathiesen ER, Deckert T. Effect of two years of strict metabolic control on progression of incipient nephropathy in insulin dependent diabetes. Lancet 1986; ;i: 1300-4.

37 Dahl-Jørgensen K, Hanssen KF, Brinchmann-Hansen O, Kierulf P, Sandvik L. Blood glucose control and progression of diabetic retinopathy and nephropathy. Seven years results from The Oslo Study (abstract). Diabetes 1990;39 (suppl 1):16A.

38 Seaquist ER, Goetz FC, Rich S, Barbosa J. Familial clustering of diabetic kidney disease. Evidence for genetic susceptibility to diabetic nephropathy. N Engl F Med 1989;320:1161-5.

Accepted 24 fune 1991
Cardiovascular Research Unit, Departments of Cardiology and Medicine, University of Edinburgh, Edinburgh EH8 9XF A D Hargreaves, MRCP, lecturer in medicine

R L Logan, MD, overseas senior research fellow

Marjory Thomson, MPHIL, senior dietitian

M F Oliver, FRCP, professor of cardiology

R A Riemersma, PHD, senior lecturer in cardiac

biochemistry

Medical Statistics Unit, Department of

Community Medicine, University of Edinburgh, Edinburgh

R A Elton, PHD, senior lecturer

Correspondence and requests for reprints to: Dr Hargreaves.

BMF 1991;303:678-81

\title{
Total cholesterol, low density lipoprotein cholesterol, and high density lipoprotein cholesterol and coronary heart disease in Scotland $/ 1$
}

\author{
A D Hargreaves, R LLogan, Marjory, Thomson, R A Elton, M F Oliver, R A Riemersma
}

Abstract

Objective-To investigate long term changes in total cholesterol, high density lipoprotein cholesterol, and low density lipoprotein cholesterol concentrations and in measures of other risk factors for coronary heart disease and to assess their importance for the development of coronary heart disease in Scottish men.

Design-Longitudinal study entailing follow up in 1988-9 of men investigated during a study in 1976.

Setting-Edinburgh, Scotland.

Subjects - 107 men from Edinburgh who had taken part in a comparative study of risk factors for heart disease with Swedish men in 1976 when aged 40.

Intervention-The men were invited to attend a follow up clinic in 1988-9 for measurement of cholesterol concentrations and other risk factor measurements. Eighty three attended and 24 refused to or could not attend.

Main outcome measures - Changes in total cholesterol, high density lipoprotein cholesterol, and low density lipoprotein cholesterol concentrations, body weight, weight to height index, prevalence of smoking, and alcohol intake; number of coronary artery disease events.

Results-Mean serum total cholesterol concentration increased over the 12 years mainly due to an increase in the low density lipoprotein cholestero fraction (from $3.53(\mathrm{SD} \mathrm{0.09)}$ to $4.56(0.11) \mathrm{mmol} / \mathrm{l}$ ) despite a reduction in high density lipoprotein cholesterol concentration. Body weight and weight to height index increased. Fewer men smoked more than 15 cigarettes/day in 1988-9 than in 1976. Blood pressure remained stable and fasting triglyceride concentrations did not change. The frequency of corneal arcus doubled. Alcohol consumption decreased significantly. Eleven men developed clinical coronary heart disease. High low density lipoprotein and low high density lipoprotein cholesterol concentrations in 1976, but not total cholesterol concentration, significantly predicted coronary heart disease $(p=0.05)$. Almost all of the men who developed coronary heart disease were smokers $(91 \% v 53 \%, \mathrm{p}<0.05)$.

Conclusion-Over 12 years the lipid profile deteriorated significantly in this healthy cohort of young men. Smoking, a low high density lipoprotein concentration and a raised low density lipoprotein concentration were all associated with coronary heart disease in middle aged Scottish men, whereas there was no association for total cholesterol concentration. The findings have implications for screening programmes.

\section{Introduction}

Mortality from coronary heart disease is not uniform in Europe, either between countries or even within a single country. In Britain, ${ }^{12}$ Scotland and Northern Ireland have the highest mortality from coronary heart disease in middle aged men. The factors causing this geographic variation are not fully understood. Regional differences in standardised mortality ratios for coronary heart disease in Scotland ${ }^{3}$ and in Britain ${ }^{4}$ cannot be explained by variations in the average total cholesterol or high density lipoprotein cholesterol concentration, although variations in smoking and blood pressure provide a partial explanation.

In 1976 a study in Edinburgh and Stockholm gathered cross sectional data and explored reasons for the threefold excess of mortality from coronary heart disease in men aged 40 from Edinburgh. ${ }^{5}$ The men from Edinburgh smoked more cigarettes, had slightly higher blood pressure, were more obese, had a greater insulin response to an oral glucose tolerance test, and had significantly lower adipose linoleic acid concentrations than men aged 40 from Stockholm. In addition they had higher fasting triglyceride and lower high density lipoprotein concentrations. ${ }^{5}$ Serum total cholesterol and low density lipoprotein cholesterol concentrations did not differ between men from the two cities. This cross sectional study suggested, therefore, that raised cholesterol concentration may not be a major contributor to the high mortality from coronary heart disease in Scotland.

In assessing coronary risk factors it is also important to collect longitudinal data. Prospective studies have identified the increased risk of coronary disease associated with raised cholesterol concentration. ${ }^{67}$ The importance of a low high density lipoprotein cholesterol concentration has been controversial. ${ }^{8-10}$ In Britain, the regional heart study initially reported the lack of an independent association between a low high density lipoprotein cholesterol and mortality from coronary heart disease, ${ }^{11}$ but subsequent reports suggest a different interpretation."

We examined whether total cholesterol, high density lipoprotein cholesterol, and low density lipoprotein cholesterol concentrations measured in the 1976 study proved to be significant factors in predicting those men 